\title{
Case Analysis: Equal Opportunity and Safety at PT. XYZ-Striving for Fairness in a Family Business
}

\author{
Alvina Greatica, Cinta Nastasya, Tommy Haryo Prakoso, Sekar Wulan Prasetyaningtyas, \\ Anita Maharani
}

Bina nusantara International University, Jakarta, Indonesia

Email: Cinta.Nastasya@gmail.com

How to cite this paper: Greatica, A., Nastasya, C., Prakoso, T. H., Prasetyaningtyas, S. W., \& Maharani, A. (2020). Case Analysis: Equal Opportunity and Safety at PT. XYZ-Striving for Fairness in a Family Business. Open Journal of Business and Management, 8, 1962-1976.

https://doi.org/10.4236/ojbm.2020.85120

Received: May 8, 2020

Accepted: August 9, 2020

Published: August 12, 2020

Copyright $\odot 2020$ by author(s) and Scientific Research Publishing Inc. This work is licensed under the Creative Commons Attribution International License (CC BY 4.0).

http://creativecommons.org/licenses/by/4.0/

\begin{abstract}
Equal opportunity and work safety are important factors in employee motivation that determine a company's success. However, not all companies are aware of the importance of the two factors, especially family businesses. Family businesses worldwide are known to tend to segregate treatment between family and non-family members. As a country that has numerous successful family businesses, Indonesia might be an interesting case to look at. This paper aims to look at the practice of equal employment opportunity in one of the biggest family businesses in Indonesia.
\end{abstract}

\section{Keywords}

Equal Opportunity Employment, Discrimination, Equal Opportunity and Performance, Equal Opportunity and Turnover, Family Business, Fairness, Procedural Justice

\section{Introduction}

The concept of equality has been a fundamental issue in law as well as in society. In an organization, the equality issue has also been the highlight among other critical issues under the spotlight. From gender segregation until biased pay (Madhani, 2015), all kinds of unequal treatment have been the classic problems longing for a solution. According to an article from Harvard Business Review (Stainback \& Devey, 2013), equal opportunity in employment has been a worldwide issue since 1964. In the US, before 1964, discrimination and segregation of employment were legal in the workplace. Only after the Civil Rights Act emerged in 1964, this issue has been started to be handled. That historical mi- 
lestone comes up with the Equal Employment Opportunity Commission (EEOC) to continuously monitor the enforcement of equal employment practice.

In Indonesia, equal employment opportunity has also been an issue waiting to be solved (Susanti \& Aan, 2018). According to the Global Gender Gap Report (2020), the percentage of women being a member of boards of directors in Indonesia companies is only $3.3 \%$. This represented the rest of the figure throughout the country, gender composition in Legislative Parliament, in Presidential Ministry, and many more. However, equal opportunity has not always been about gender segregation. Racial background, religion, or sometimes political view also become the reason for some companies or organizations in mapping their existing and/or future human capital planning.

Taking equal employment opportunities to further extent, it is interesting to see whether family companies and non-family companies in Indonesia are different in this sense. In the absence of fairness and justice principles, family companies are often faced with the tradeoff between emotion and economic performance as stated by Samara and Arenas (2017). In several cases, family businesses that promote fairness in their workplace are proven to improve economic performance along with the satisfaction and commitment from family and non-family members inside the company (Pimentel, Pires, \& Almeida, 2020). According to Samara and Arenas (2017), family businesses can significantly benefit from promoting the practice of fairness in the workplace. However, according to several articles, it has become a rather common practice for a family business to conduct unfair practices by offering distinctive treatment to employees that are family members (Samara and Arenas, 2017). For instance, Magid Glove permitted flexible work schedule for family members (Ward and Perricelli, 2005), at Jones Food the top management is dominated by a family member (Schein, 1999) or in the case of Lazard LLC, where family members receive a higher salary than non-family member even if the position is the same (Subramanian \& Sherman, 2007).

Literature in this domain is still limited. Therefore, aiming to contribute to the literature of this area, this study is taking PT. XYZ as one example case. PT. XYZ is an Indonesian family-owned company, as part of the bigger owning-group, located in the center of Jakarta city. It operates in the property management industry and has several business units operating under the company. The objective of this study is to check the practice of equal employment opportunity in PT. XYZ, by answering the following questions:

RQ1: How is the practice of Equal Employment Opportunity (EEO) in PT. $\mathrm{XYZ}$ ?

RQ2: How is the EEO practice in PT. XYZ affecting company performance* (compared to the industry average)?

*performance indicator: Employee Turnover Rate, Employee Satisfaction.

This paper consists of five sections. This first section is the introduction where 
the authors briefly explained the scope of the study. The second section will mainly cover the literature review explaining the concepts and theories used as the basis of this study. The third section will explain the methodology used to conduct this study, as well as the conceptual framework of this study. In the fourth section, the result of the analysis will be discussed and finally, the fifth section will conclude the findings of this study.

\section{Literature Review}

\subsection{Equal Employment Opportunity}

Government departments in America initiated the Equal Employment Opportunity Commission (EEOC) to abolish discrimination between races, religions, national origin, disability, gender, age, skin color for any employee who works there. The EEOC was not always there to protect employee rights, but in the 1960s, when segregation and racial problems were heated up, it became clear that such protection was needed (Davis, n.d.).

EEO security is provided by Federal and State Fair-Jobs legislation enforced by the Equal Employment Opportunity Commission (EEOC) and its affiliates. The basic EEO definition (or equal opportunity for work) is the idea that everyone should be treated fairly when considered for particular employment decisions (including hiring, promotion, termination, compensation, etc.)

\subsection{Family Business}

Related to studies by Chua, Chrisman, and Sharma (1999), the family business is a corporation owned or run by members of the same family. Businesses that have been owned or run by the family must form the company's vision and mission where the vision and mission is a strong alliance dominated by family members themselves, and things like this affecting the great potential between families or generations of the family themselves to continue the business. It was further suggested that the willingness of family business owners to preserve their socio-emotional wealth is what distinguishes family businesses from other forms of business (SEW) (Gómez-Mejía, Haynes, Núñez-Nickel, Jacobson, \& Moyano-Fuentes, 2007). The social-emotional wealth (SEW) itself is a definition in which the usefulness of family ownership in the company itself is enormous from the economic aspects of the business that influence the family's status in terms of its profits, to the protection of dynasties and family values. (Berrone, Cruz, \& Gomez-Mejia, 2012; Kellermanns, Eddleston, \& Zellweger, 2012). According to the study by Cruz, Larraza-Kintana, Garcés-Galdeano, \& Berrone, (2014), family firms' social activities are founded to be more sensitive to declining organizational performance.

\subsection{Family Business vs. Non-Family Business}

As argued by Ayres, a proper concept for distributing resources within the family circle (both financial and emotional) is usually based on needs. Families are 
ordered primarily based on hierarchies of the relationship between parents and their children. This behavioral trend reverses as their child starts to grow and the needs are slowly met, the needs of their aging parents for another successor (Tirdasari \& Dhewanto, 2012). In short, the family stands as an organization structured to meet the needs of each member, usually first by those who are still young, then those who have aged (Van der Heyden, Blondel, \& Carlock, 2005). Fair process: Striving for justice in a family business. Family Business Review, 18(1), 1-21.

In comparison, the hierarchies a non-family company is based on each competency, accepted by past achievements and perceived prospects for the future. One's successful performance will strengthen its role and authority (Otley, 1999; Parker, 2000; Van der Heyden, Blondel, \& Carlock, 2005). Thus, the concept of resource distribution within a company is that of results and merit-based equity, and not needs-based. Competent managers are heard well, given more trust and responsibility, they could also earn greater rewards when proven to be successful, as stated by Chrisman, Memili, \& Misra, (2014). These types of managers might be allocated to more resources when following particular acts and strategies - because they are considered to deserve this allocation more than their less productive peers (Van der Heyden, Blondel, \& Carlock, 2005).

The case is different in regards to shareholding or control of equities. The rule for resource allocations and, to an even greater extent than benefits allocations are equality: where all shareholders are expected to earn the same dividends, at least within their class. The initial price of each share is supposed to be the same for both parties, and the details should be equally distributed to all parties. That is exactly why "insider knowledge" is considered to create an economic disadvantage for "outsiders" (and in some countries it is illegal).

\subsection{Complex Nature of a Family Business}

According to Block \& Jaskiewicz in 2007, they stated that both family and non-family employees are allowed to make special and distinct contributions to the family business. Non-family workers may express their opinions based on fair and reasonable reasoning and will be less likely to incur expenses from private benefits than family workers

According to Chua et al. (2009), non-family employees come from a larger pool of talent as they seem to be competent with each other and seem to be more qualified because of the experience they obtain on behalf of the family in the business, without the control of "power of the family." Research shows that employees in the family will improve their business skills early on as they are accustomed to their everyday lives and have a certain point of view because this is their family business, which is something they also get from being informed about the company themselves at home (Memili, Chrisman, Chua, Chang, \& Kellermanns, 2011), therefore a family employee has the potential to acquire secret business information, a form of information that is not readily conveyed to 
non-family employees either by education or training. What's more, with the emotional bond between families that they already know the meaning of the company itself in advance than workers who are not part of this family business. Dawson (2012) said that for any family member who is a company employee in the family business, they will be more driven and dedicated to their family business as the benefits that they get will be greater than the others. But seeing this from all the elements in the literature, if non-family workers with more or less the same ability as family workers remain equal or are granted a different classification, and from which they see equal opportunities. That as an employee, concerns would undoubtedly arise as to how they can be evaluated with the same criterion.

As stated by Habbershon \& Williams (1999) the ability of family and non-family workers to have a range of information, skills and services vary widely depending on the workers themselves ., and Dawson and Kidwell (2012) added that ideally, this good attribute is used by both family and non-family workers, but it is less understood why they would do it. To reconcile these two forms of human capital in this complex environment, the researchers suggest that the pursuit of equity should be the starting point for family business decision-makers to find a balance between equality and fairness in the workforce of family businesses.

\subsection{Fairness}

Greenberg (1986) applied the principles of procedural justice to business problems. His early concern in promotional and pay decisions was focused on performance evaluation. Organizations, like nations, are human entities particularly vulnerable to procedural justice. Whenever a fair process exists, trust, dedication, and harmony will follow (Greenberg, 1990; Khourshed, 2012). Initial work on procedural justice established the primary finding that expectations of fairness were affected by the existence of legal procedures.

An opposed procedure, where each party can present each value and argument, compared to the Inquisition procedure, where the parties are questioned. In particular, the capability to speak is associated as a discriminatory element in supporting justice (Lind \& Taylor, 1988).

According to Leventhal (1980) broadened the concerns above the juridical system and proposed six procedural fairness principles towards making decision procedures:

- The consistency of a procedure, regarding the person and time.

- A bias suppression by the decision-maker.

- Information accuracy.

- Correct ability.

- Representativeness, each procedure needs to reflect basic concerns, value, and putting aside personal concerns.

- Ethicality follows standards of ethics and norms. 


\subsection{Procedural Justice in a Family Business}

Lansberg (1989) was one of the early scholars who address justice in a family business that has been identified as "messy and complicated." He characterized it by three types of justice with a view to clarification:

1) Distributive justice, related to resource distribution and conflict between members.

2) Procedural fairness primarily considers as deciding the actors involved in the taking of particular decisions

3) Retributive justice, where the deals with the discipline of members who violate unique norms.

Family-company members usually find equal ownership or transition of management in terms of distribution, i.e. assets allocation: what individual member acquires (e.g., wealth) or how members are affected (e.g. appointed to become a senior management position). In Ayres's (1996) article regarding family justice, he proposed that the success of ownership should be based on the desire of the family members itself. They need concepts that are only one of the concepts that can be implemented when deciding results, but a crucial one within families. The other two concepts widely cited when applying distributive justice are fairness and equality (Baldridge \& Schulze, 1999).

\subsection{Career Paths and Power of Other Participants}

Holding family members in the family business itself need dedication and honesty, as there will be other variables that are often less professional when it comes to doing business (Mahto, Vora, McDowell, \& Khanin, 2020). For some cases, some family companies elect the company's leaders, not the family but the company's non-family to settle disputes within the company itself, which they need as a different viewpoint and it may also the cost of paying the chief, and not just because their family's reputation is not significantly damaged in terms of publicity (Barach \& Ganitsky, 1995). However, when their performance did not meet the family shareholders expectations, these qualified CEOs and other outsiders were replaced which fixed the problems of each company and improved their performance (Barach \& Ganitsky, 1995).

\subsection{Corporate Culture and Organizational Structure}

An organization's structure can pose almost insurmountable barriers to the career advancement of potential successors (Lee, Lim, \& Lim, 2003). But partnerships with alternate sources and job descriptions that overcome these institutional barriers are typically feasible. A similar structural adjustment can accommodate CEO and offspring personalities, particularly regarding the need for autonomy of the offspring as opposed to tutoring. The organization should be prepared for potential leaders starting from the lowest entry-level where he can know and understand many things and have a lot of networking for business growth or with an approach to the family business owner (Barach. Ganitsky et 
al., 1988).

The basic distinctions between parent and child are usually best preserved at first. Initially, at a branch office or any major in finance, independent sons and daughters may be better off. Usually, closer mentoring is helpful and possible if the organization is accustomed to parent-boss and child-employee.

The CEO, whose leader is the family itself, would help smooth the transfer of offspring from the family by developing a "secret" organizational diagram structure for handling all forms of business related to rivals, handling everything inside the company with a separate agenda (Feinberg, 1990).

\section{Research Design}

The researchers use the analysis of this study by using qualitative methods. Which, according to Myers (2019), qualitative research aims to encourage researchers to understand people in their social and cultural context in which they live because researchers need to understand what respondents mean with the presence of very deep information. Qualitative research aims at understanding and reflecting people's perceptions and behaviors as they encounter, interact, and live in the circumstances (Reicher, 2000). A list of questions will be sent out in April 2020, Qualitative evidence collected by the researcher in this study is by using in-depth interviews and informal conversations using phone call due to today's pandemic situation. There will be three respondents, the first one is the high-rank HR officer from the sample company. The second respondent will be representative of the nonfamily-member employee, and the last respondent will be representative of a family-member employee. The company is an integrated property management company. The interviews were conducted in Bahasa Indonesia, and the written stage of the study was the translation into English. A model is prepared based on the supporting literature to address the above. The variables included in the models contribute to the determinant to which the performance of companies is influenced by family and non-family businesses.

The analysis will be started by conducting in-depth interviews, where the answers will then be grouped based on similar keywords. Questions include employee opinions on equality in the company, information about how long the employee has been working at this company. Interviews will be conducted with the HR officer, family and non-family employees at the time and location that is convenient for the respondents. The three respondents are representing the perspective of each, as this will give comprehensive insights on how equality is being conducted in the sample company, from HR as the platform/program provider, and also from the point of views of family and non-family employee as a direct user of the platform/program, as well as check the validity and consistency of the testimonies given. All participants who participated in this research must sign the researcher's consent form to provide information about their role in the office and to conceal their identity of the full name for mutual comfort. 


\section{Interview Result}

\section{In-depth Interview Guideline}

Good morning/afternoon/evening Sir/Mam.

We are students of Binus Business School, Master of Management study.

Thank you for allocating your time to do this interview with us, as part of the requirement for our final project.

\section{Introduction}

1) What is your current job position in this company?

2) How long have you been working in this company?

3) In general, how long have you been working as an HR?

\section{Opinion on equal employment opportunity}

1) What do you think about equal employment opportunity?

2) In your opinion, what are the examples of equal employment opportunity?

3) In your opinion, is equal employment opportunity important?

\section{Equal employment opportunity practice in your company}

1) In your company, is equal employment opportunity implemented?

2) If yes/no, what is the reason?

3) If yes, how is it implemented?

4) If no, what principles that are being implemented in your company?

\section{General}

Is there any regulation on equal employment opportunity?

\section{Closing part}

Appreciation and disclaimer

Once again, thank you for your participation in this interview.

Your personal and company identity will be kept confidential to your privacy.

\section{Interview 1 (HR)}

Respondent Profile

Name: Mrs. SR

Position: Senior Manager HR 10 years experience in PT. XYZ

Summary of insights:

1) To her opinion, EEO is a very supportive aspect of the company's success, in this era of VUCA (Volatility, Uncertainty, Complexity, and Ambiguity) that requires the company to be agile.

2) EEO is important for the company to create a competitive human resource to face nowadays challenges.

3) All aspect of this company complies to the EEO Principles.

4) There is no segregation or any special treatment given to anyone.

5) Talent Mapping process in this company is purely based on competency, potential, and performance.

6) In a case when there is any individual that is related to the family wanting to join the company, the owner representative will not interfere in any process. The recruitment and placement of that individual will be according to the standardized process, and according to the need of the company. 


\section{Interview 2 (Nonfamily-member Employee)}

Respondent Profile

Name: Mr. KP

Position: General Manager Marketing Communications \& Operations - 14 years experience in PT. XYZ.

Summary of insights:

1) To his opinion, EEO in terms of theory it should be equal, but in practice it can't be like that because of its many dimensions, starting from Gender, disabilities, educational background (experience) and the most standard is performance, and performance appraisal is quite fair, what is difficult is its dimension.

2) Fairness in the job is to provide opportunities for employees who are entitled to get it in terms of dimensions and performance during their work. Not from how long he worked, but from the results he did for the company.

3) According to him, the leader is very influential in the company and also his team, if the leader can provide direction then the team will also get clarity. In practice, the implementation of equality in the work area is also depending on the leadership of each leader.

4) Even though this company is a family company, they treat all employees the same, he isn't part of the family, but he sees the development during the 14 years where he worked in this company, that the family element is more about the culture of this company itself, it can be seen from our low turnover in this sense non-family employees also feel safe.

5) This company is very demonstrative, where they exchange ideas among others, discussion, and the most important thing is that trust level. And also, the owner of this company loves to involve in an open discussion through the leaders based on each input.

Interview 3 (Family-member employee)

Respondent Profile

Name: Mr. RDS

Position: Officer Event \& Promotions 2 years experience in PT. XYZ

Summary of insights:

1) To his opinion, EEO is important to motivate employees and ensure that everyone has the same opportunity to grow. Also, it is supported by the regulation from the government.

2) EEO also plays an important role in shaping a good company culture.

3) As a family member, he testified that he never received any kind of special treatment from the company, especially when it comes to remuneration package and the obligation to comply with the company's policy.

4) He may have noticed some different communication styles that come from some people that are aware of his bloodline, but not from everyone, and it has nothing to do with work.

\section{Keywords from the interviews:}

Company Challenges, Company Culture, Competitive, CV, Education Level, 
Fairness, Leadership, Opportunity, Supportive, Motivation, Owner Representative, Leader, Government Regulation, Personal Background, Qualifications, Trust, VUCA.

\section{Analysis and Discussion}

Based on the interview results, several things can be concluded:

\section{1) Opinion on Equal Employment Opportunity}

All three respondents are generally agreed that EEO is important. It is said that EEO will help the company to face the challenges ahead and hence, lead to the company's success. It is also mentioned that EEO is important to motivate employees to perform. However, despite the importance of EEO, one of the respondents testified that in practice, the implementation of EEO is not easy. Several factors are affecting the implementation of EEO, one of which is the leadership of each leader. Because of fairness in the job, employees who are entitled to get it in terms of dimensions and performance during their work are given opportunities. Not from the length of service but from the work results and performance given to the company.

\section{2) The Implementation and Practice of EEO in the Company}

It is mentioned by Senior Manager HR that all HR-related aspects in the company comply with the principles of EEO. This testimony was confirmed by the two respondents (as users), that in doing the Talent Mapping, the company purely sees into the competency, capability, and performance, without any considerations related to the background of the employee. It shows that this company implements EEO. Talent mapping, as the basis of employee promotions, is carried out purely by considering objective measures, such as competency, capability, and performance which show fairness for family and non-family members of the company.

3) Segregation and Distinction of Treatments between Family and Nonfamily

Align with the testimony from the Senior Manager of HR, the two respondents (as users) said that there is no segregation of treatments between employees, especially to the family member. Every HR-related aspect is conducted according to the applied regulations and policies, all same for every employee. However, the family-member employee testified that he may notice some differences in the way people communicate with him, although it cannot be proven to be related to his status as family-member. Nonetheless, he further clarified that this has nothing to do with work.

Based on the three types of justice by Lansberg (1989), it can also be concluded:

1) Distributive justice, related to resource distribution and conflict between members. Resources are being distributed equally between Family and Nonfamily employees. Remuneration packages, work load, area of responsibilities is distributed in accordance to the position held by each employee. 
2) Procedural fairness primarily considers as deciding the actors involved in the taking of particular decisions. Those decisions are made purely based on authorities related to each professional position. Although owners' opinions are mainly involved in the strategic decision-making process, the final call will be taken by related authorities.

3) Retributive justice, where the deals with the discipline of members who violate unique norms.

That all employees are treated equally, where every achievement will be rewarded as any violation will be punished according to applied regulations and policies.

\section{Conclusion}

In our research results from this family company, it shows that Equal Employment Opportunity (EEO) is very important in a company with various aspects such as gender (Zhang, 2020), the background of education and experience, disability, and many more. Since, this research was carried out at the time of the pandemic situation which will result as researchers limitation, and the accuracy of this study derived from contrasts between employees who came from families in a short period of work experience and non-family employees and one of the HR employees from the company who already has a position and work experience of more than 10 years, while it seems that these three participants should show the quality of this research in applying equal opportunities in a family business.

EEO is important, however, the implementation will not be easy. It shows that EEO is being implemented in this company for family members and non-family members based on the results of our interview with the employees in the company. Talent mapping, as the basis of employee promotions, is conducted purely by considering objective measurements, such as competency, capability, and performance. And there is no segregation between family and nonfamily employees, as argued by Mullins, Charbonneau, \& Riccucci (2020), the absence of segregation or discrimination will improve satisfaction and lower employee turnover.

According to our research, the implementation of EEO depends on the leaders (managers). Because even though the platform for EEO is made available by the company through the HR programs, without a strong leadership from the leaders, it will be difficult for EEO to be implemented. For instance, a good leader should not favor any of his/her subordinates, but should always prioritize the career development plan based on objective performance measurement (Larkin, Pierce, \& Gino, 2012; Sánchez-Flores, Ojeda-Benítez, Cruz-Sotelo, \& Navarro-González, 2020; Walters \& Helman, 2020), and on top of that, based on the company's needs. Good leaders are also needed for employees to get involved and to ensure that each team member feel comfortable in the company. One of the respondents said that good leaders can foster enthusiasm and commitment 
to others, that they are suitable among employees, and connect them to organizational objectives. Here we can also see that this company promotes a family culture where everything is done together so that the results can be in line with the wishes and that employees who work can prosper so that they can also be loyal to the company even if they are not part of the family. They also build trust in the behavior of their employees and strengthen their trust; good leaders recognize their employees constantly. Effective communication functions as a channel for encouraging employee involvement (career development, appreciation, security, adequate resources, interest in welfare management, autonomy, etc.). The main driver of engagement is internal communication (Baumruk, Gorman, \& Gorman, 2006; Hoover, 2005; Woodruffe, 2006; Yates, 2006). Communication is also a part of employee-friendly policies, as stated by Kang, \& Kim, (2020).

Hoover added that a successful and good communication process in retaining employees who work today involves them in difficult times and the organization must, of course, remain strong to maintain it (Hoover, 2005). The involvement of employees in the decision-making process shows communication in a company and a discussion between employees and the company about their involvement shows that the company appreciates their employees and this will result in a small turnover rate (Tura, 2020) as employees feel appreciated by giving opinions to Baumruk et al. (2006). Jewell, Jewell, \& Kaufman, (2020) also stated that communication is an essential part of High-Performance Work System (HPWS).

Fair treatment of employees (family and non-family) is also very important to the company (Pimentel, Pires, \& Almeida, 2020). A manager's treatment must be fair in providing opportunities for growth and promotion to each employee with their needs, skills, and motivation, and must be recognized reasonably like all of the colleagues.

Family friendliness is becoming their culture. If the company shows concern for the employee's family, involvement will be greatly influenced (everyone is usually emotionally attached to the family). And within this company, they have a different and interesting strategy where (family and non-family members) are involved in corporate decision making. It will be seen that by increasing employee mobility, it will affect the balance of work-life is the right agreement of role-time commitments that take into account good functions at work and home, with the lowest conflict role and maximum satisfaction (Sverko, Arambasic, \& Galesic, 2002). The balance of work-life must also be considered because the comfort of the employee will affect his loyalty, if he has a pleasant and balanced arrangement between the work duties of the employee and his personal life, it can be ensured that the employee will long work in the company (Sverko et al., 2002).

\section{Conflicts of Interest}

The authors declare no conflicts of interest regarding the publication of this paper. 


\section{References}

Ayres, G. (1996). Rough Family Justice: Equity in Family Business Succession Planning. In The Best of FBR (pp. 181-190). Boston, MA: The Family Firm Institute, Inc.

Baldridge, D. C., \& Schulze, W. S. (1999). Fairness in Family Firms: An Organizational Justice Perspective on Agency Problems. In the Academy of Management Proceedings (Vol. 1999, pp. C1-C6). Briarcliff Manor, NY: Academy of Management. https://doi.org/10.5465/apbpp.1999.27600155

Barach, J. A., \& Ganitsky, J. B. (1995). Successful Succession in a Family Business. Family Business Review, 8, 131-155. https://doi.org/10.1111/j.1741-6248.1995.00131.x

Baumruk, R., Gorman, B., \& Gorman, R. E. (2006). Why Managers Are Crucial to Increasing Engagement. Strategic HR Review, 5, 24-27.

https://doi.org/10.1108/14754390680000863

Berrone, P., Cruz, C., \& Gomez-Mejia, L. R. (2012). Socioemotional Wealth in Family Firms: Theoretical Dimensions, Assessment Approaches, and Agenda for Future Research. Family Business Review, 25, 258-279. https://doi.org/10.1177/0894486511435355

Block, J. H., \& Jaskiewicz, P. (2007). The Impact of Nonfamily Executives on Firm Value: Conclusions from the Jensen-Meckling Theory of the Firm. https://papers.ssrn.com/sol3/papers.cfm?abstract id=947047 https://doi.org/10.2139/ssrn.947047

Chrisman, J. J., Memili, E., \& Misra, K. (2014). Nonfamily Managers, Family Firms, and the Winner's Curse: The Influence of Noneconomic Goals and Bounded Rationality. Entrepreneurship Theory and Practice, 38, 1103-1127. https://doi.org/10.1111/etap.12014

Chua, J. H., Chrisman, J. J., \& Bergiel, E. B. (2009). An Agency Theoretic Analysis of the Professionalized Family Firm. Entrepreneurship Theory and Practice, 33, 355-372. https://doi.org/10.1111/j.1540-6520.2009.00294.x

Chua, J. H., Chrisman, J. J., \& Sharma, P. (1999). Defining the Family Business by Behavior. Entrepreneurship Theory and Practice, 23, 19-39. https://doi.org/10.1177/104225879902300402

Cruz, C., Larraza-Kintana, M., Garcés-Galdeano, L., \& Berrone, P. (2014). Are Family Firms More Socially Responsible? Entrepreneurship Theory and Practice, 38, 1295-1316. https://doi.org/10.1111/etap.12125

Davis, J. (n.d.). A Brief History of the Equal Employment Opportunity Commission. [Online] Davis Law Firm.

https://jeffdavislawfirm.com/a-brief-history-of-the-equal-employment-opportunity-co mmission

Dawson, A. (2012). Human Capital in Family Businesses: Focusing on the Individual Level. Journal of Family Business Strategy, 3, 3-11. https://doi.org/10.1016/j.jfbs.2011.12.001

Global Gender Gap Report 2020. http://www3.weforum.org/docs/WEF GGGR 2020.pdf

Gómez-Mejía, L. R., Haynes, K. T., Núñez-Nickel, M., Jacobson, K. J. L., \& Moyano-Fuentes, J. (2007). Socioemotional Wealth and Business Risks in Family-Controlled Firms: Evidence from Spanish Olive Oil Mills. Administrative Science Quarterly, 52, 106-137. https://doi.org/10.2189/asqu.52.1.106

Greenberg, J. (1986). Determinants of Perceived Fairness of Performance Evaluations. Journal of Applied Psychology, 71, 340-342.

https://doi.org/10.1037/0021-9010.71.2.340 
Greenberg, J. (1990). Organizational Justice: Yesterday, Today, and Tomorrow. Journal of Management, 16, 399-432. https://doi.org/10.1177/014920639001600208

Habbershon, T. G., \& Williams, M. L. (1999). A Resource-Based Framework for Assessing the Strategic Advantages of Family Firms. Family Business Review, 12, 1-25.

https://doi.org/10.1111/j.1741-6248.1999.00001.x

Hoover, G. (2005). Maintaining Employee Engagement When Communicating Difficult Issues. Communication World, 22, 25-27.

Jewell, D. O., Jewell, S. F., \& Kaufman, B. E. (2020). Designing and Implementing High-Performance Work Systems: Insights from Consulting Practice for Academic Researchers. Human Resource Management Review, Article ID: 100749. https://doi.org/10.1016/j.hrmr.2020.100749

Kang, J. K., \& Kim, J. (2020). Do Family Firms Invest More than Nonfamily Firms in Employee-Friendly Policies? Management Science, 66, 1300-1324. https://doi.org/10.1287/mnsc.2018.3231

Kellermanns, F. W., Eddleston, K. A., \& Zellweger, T. M. (2012). Extending the Socioemotional Wealth Perspective: A Look at the Dark Side. Entrepreneurship Theory and Practice, 36, 1175-1182. https://doi.org/10.1111/j.1540-6520.2012.00544.x

Khourshed, N. F. (2012). Process Concept to Performance Management. International Journal of Business and Management Studies, 4, 147-156.

Larkin, I., Pierce, L., \& Gino, F. (2012). The Psychological Costs of Pay-for-Performance: Implications for the Strategic Compensation of Employees. Strategic Management Journal, 33, 1194-1214. https://doi.org/10.1002/smj.1974

Lee, K. S., Lim, G. H., \& Lim, W. S. (2003). Family Business Succession: Appropriation Risk and Choice of Successor. Academy of Management Review, 28, 657-666. https://doi.org/10.5465/amr.2003.10899446

Leventhal, G. S. (1980). What Should Be Done with Equity Theory? New Approaches to the Study of Fairness in Social Relationships. In K. Gergen, M. Greenberg, \& R. Willis (Eds.), Social Exchange: Advances in Theory and Research (pp. 27-55). New York: Plenum Press. https://doi.org/10.1007/978-1-4613-3087-5 2

Lind, E. A., \& Tyler, T. R. (1988). The Social Psychology of Procedural Justice. New York/London: Plenum Press. https://doi.org/10.1007/978-1-4899-2115-4

Madhani, P. M. (2015). Sales Compensation Strategy: An Optimal Design of Pay Level and Pay Mix. Compensation \& Benefits Review, 47, 107-120. https://doi.org/10.1177/0886368715614940

Mahto, R. V., Vora, G., McDowell, W. C., \& Khanin, D. (2020). Family Member Commitment, the Opportunity Costs of Staying, and Turnover Intentions. Journal of Business Research, 108, 9-19. https://doi.org/10.1016/j.jbusres.2019.10.013

Memili, E., Chrisman, J. J., Chua, J. H., Chang, E. P., \& Kellermanns, F. W. (2011). The Determinants of Family Firms' Subcontracting: A Transaction Cost Perspective. Journal of Family Business Strategy, 2, 26-33. https://doi.org/10.1016/j.jfbs.2011.01.003

Mullins, L. B., Charbonneau, É., \& Riccucci, N. M. (2020). The Effects of Family Responsibilities Discrimination on Public Employees' Satisfaction and Turnover Intentions: Can Flexible Work Arrangements Help? Review of Public Personnel Administration, 0734371X19894035. https://doi.org/10.1177/0734371X19894035

Myers, M. D. (2019). Qualitative Research in Business and Management. Thousand Oaks, CA: Sage Publications Limited.

Otley, D. (1999). Performance Management: A Framework for Management Control Systems Research. Management Accounting Research, 10, 363-382. 
https://doi.org/10.1006/mare.1999.0115

Parker, C. (2000). Performance Measurement. Work Study, 49, 63-66. https://doi.org/10.1108/00438020010311197

Pimentel, D., Pires, J. S., \& Almeida, P. L. (2020). Perceptions of Organizational Justice and Commitment of Non-Family Employees in Family and Non-Family Firms. International Journal of Organization Theory \& Behavior. https://doi.org/10.1108/IJOTB-07-2019-0082

Reicher, S. (2000). Against Methodology: Some Comments on Elliott, Fischer, and Rennie. The British Journal of Clinical Psychology, 39, 1-6. https://doi.org/10.1348/014466500163031

Samara, G., \& Arenas, D. (2017). Practicing Fairness in the Family Business Workplace. Business Horizons, 60, 647-655. https://doi.org/10.1016/j.bushor.2017.05.008

Sánchez-Flores, R. B., Ojeda-Benítez, S., Cruz-Sotelo, S. E., \& Navarro-González, C. R. (2020). Supply Chain Performance Improvement: A Sustainable Perspective. In Techniques, Tools, and Methodologies Applied to Global Supply Chain Ecosystems (pp. 333-358). Cham: Springer. https://doi.org/10.1007/978-3-030-26488-8 15

Stainback, K., \& Devey, D. (2013). Research: Your Firm Probably Isn't an Equal Opportunity Employer. Harvard Business Review.

https://hbr.org/2013/06/is-your-firm-really-an-equal-o

Subramanian, G., \& Sherman, E. (2007). Lazard LLC (HBS Case \#907-046). Boston, MA: Harvard Business School Publishing.

Susanti, A. (2018). Kesetaraan gender di indonesia.

Sverko, B., Arambasic, L., \& Galesic, M. (2002). Work-Life Balance among Croatian Employees: Role Time Commitment, Work-Home Interference, and Wellbeing. Social Science Information, 41, 281-301. https://doi.org/10.1177/0539018402041002006

Tirdasari, N. L., \& Dhewanto, W. (2012). Family Business Succession in Indonesia: A Study of the Hospitality Industry. Procedia-Social and Behavioral Sciences, 57, 69-74. https://doi.org/10.1016/j.sbspro.2012.09.1159

Tura, A. S. (2020). Determinants of Employee's Turnover: A Case Study at MaddaWalabu University. Advances in Management and Applied Economics, 10, 33-59.

Van der Heyden, L., Blondel, C., \& Carlock, R. S. (2005). Fair Process: Striving for Justice in a Family Business. Family Business Review, 18, 1-21. https://doi.org/10.1111/j.1741-6248.2005.00027.x

Walters, D., \& Helman, D. (2020). Performance Management: Value Drivers and Strategic Value Builders. In Strategic Capability Response Analysis (pp. 75-98). Cham: Springer. https://doi.org/10.1007/978-3-030-22944-3 4

Ward, J. L., \& Perricelli, S. G. (2005). Magid Glove and Safety Manufacturing Co. Boston, MA: Harvard Business School Publishing. https://doi.org/10.4135/9781526447531

Zhang, L. (2020). An Institutional Approach to Gender Diversity and Firm Performance. Organization Science, 31, 439-457. https://doi.org/10.1287/orsc.2019.1297 